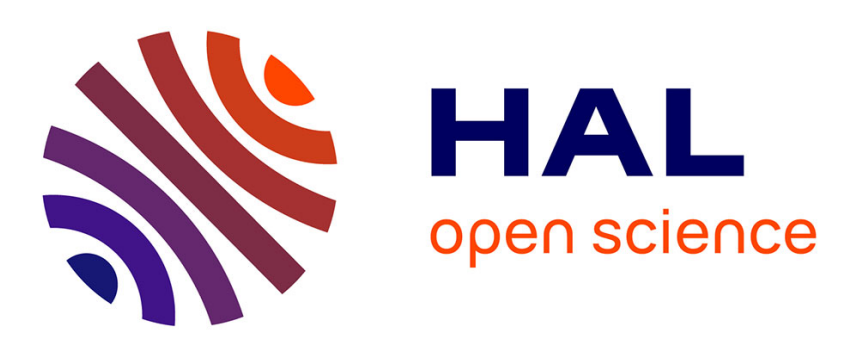

\title{
Cyclopentadienyliron dicarbonyl dimer: A simple tool for the hydrosilylation of aldehydes and ketones under air
}

Thais Cordeiro Jung, Gilles Argouarch, Pierre van De Weghe

\section{- To cite this version:}

Thais Cordeiro Jung, Gilles Argouarch, Pierre van De Weghe. Cyclopentadienyliron dicarbonyl dimer: A simple tool for the hydrosilylation of aldehydes and ketones under air. Catalysis Communications, 2016, 78, pp.52-54. 10.1016/j.catcom.2016.01.033 . hal-01269741

HAL Id: hal-01269741

https://hal-univ-rennes1.archives-ouvertes.fr/hal-01269741

Submitted on 11 Feb 2016

HAL is a multi-disciplinary open access archive for the deposit and dissemination of scientific research documents, whether they are published or not. The documents may come from teaching and research institutions in France or abroad, or from public or private research centers.
L'archive ouverte pluridisciplinaire HAL, est destinée au dépôt et à la diffusion de documents scientifiques de niveau recherche, publiés ou non, émanant des établissements d'enseignement et de recherche français ou étrangers, des laboratoires publics ou privés. 


\title{
Cyclopentadienyliron dicarbonyl dimer: a simple tool for the
}

\section{hydrosilylation of aldehydes and ketones under air}

Thais Cordeiro Jung, Gilles Argouarch*, Pierre van de Weghe

Université de Rennes 1, UMR CNRS 6226, Institut des Sciences Chimiques de Rennes, Equipe PNSCM, UFR des Sciences Biologiques et Pharmaceutiques, 2 Avenue du Professeur Léon Bernard, 35043 Rennes Cedex, France

E-mail: gilles.argouarch@univ-rennes1.fr

Keywords: Aldehydes, Hydrosilylation, Iron, Ketones, Reduction

\begin{abstract}
The readily available iron complex $\left[\mathrm{CpFe}(\mathrm{CO})_{2}\right]_{2}(\mathbf{1})$ exhibits good catalytic activity in the hydrosilylation of aldehydes and ketones in the presence of diethoxymethylsilane. The procedure described is air-tolerant and applicable to a wide range of substrates.
\end{abstract}




\section{Introduction}

The replacement of precious metals with more abundant and less toxic first-row transition metals in homogeneous catalysis is an important goal of modern synthetic organic chemistry. Great achievements in the field of iron-catalysed hydrosilylation of aldehydes and ketones have been realised over the past decade [1]. This reduction reaction consists of the addition of a hydrosilane to a carbonyl group under mild conditions, forming a silyl ether intermediate whose hydrolysis releases the corresponding primary or secondary alcohol. Several iron-based catalyst systems have been developed for both asymmetric [25] and non-asymmetric [6-22] hydrosilylation reactions. In particular, the groups of Guan [6], Li [7], Darcel [8], Tilley [9] and Chirik [10] have successfully synthesized new iron-based catalysts that have shown excellent activities in the non-asymmetric hydrosilylation of a wide range of aldehydes and ketones. However, most of these catalyst systems are elaborated well-defined iron complexes featuring various stabilizing ligands. The preparation of such pre-catalysts often requires considerable synthetic effort and resources, which offset the economic advantages of an inexpensive metal centre, potentially to an impractical and unsustainable degree. We became interested in identifying a readily available and stable iron complex suitable for straightforward-sustainable hydrosilylation.

The dinuclear iron(I) complex $\left[\mathrm{CpFe}(\mathrm{CO})_{2}\right]_{2}(\mathbf{1})\left(\mathrm{Cp}\right.$ : cyclopentadienyl $\left.=\eta^{5}-\mathrm{C}_{5} \mathrm{H}_{5}\right)$ is one of the oldest and the most studied organometallic compounds, and is well known for its extensive use as a cheap and common precursor to many iron carbonyl derivatives [23]. On the other hand, when considering the ease of metal carbonyls to be thermally or photochemically activated, there are relatively few reactions in which 1 serves directly as the effective pre-catalyst. Nonetheless, dehydrocoupling of amine-boranes [24], dehydration of amides to nitriles [25], living radical polymerisation [26], and reductive amination of unsaturated hydrocarbons [27], among others, have been previously reported. Herein, we disclose our results concerning the hydrosilylation of aldehydes and ketones catalysed by complex 1 .

\section{Results and Discussion}




\section{ACCEPTED MANUSCRIPT}

After initial screening of several hydride sources ${ }^{\Uparrow}$ and solvents using 4-bromobenzaldehyde (2a) as a model substrate, the relatively cheap diethoxymethylsilane was identified as the best reducing agent and toluene as a solvent of choice. Thus, reaction of $\mathbf{2 a}$ in toluene solution at $100{ }^{\circ} \mathrm{C}$ in the presence of $(\mathrm{EtO})_{2} \mathrm{MeSiH}$ (1.5 equiv.) and $\mathbf{1}(2 \mathrm{~mol} \%)$ for $16 \mathrm{~h}$ under an inert atmosphere gave alcohol $\mathbf{3 a}$ with a very good conversion of $97 \%$ (Table 1 , entry 1 ).

\section{Table 1}

Optimization study for the hydrosilylation of $\mathbf{2 a}$ with $\mathbf{1}$ as the pre-catalyst.

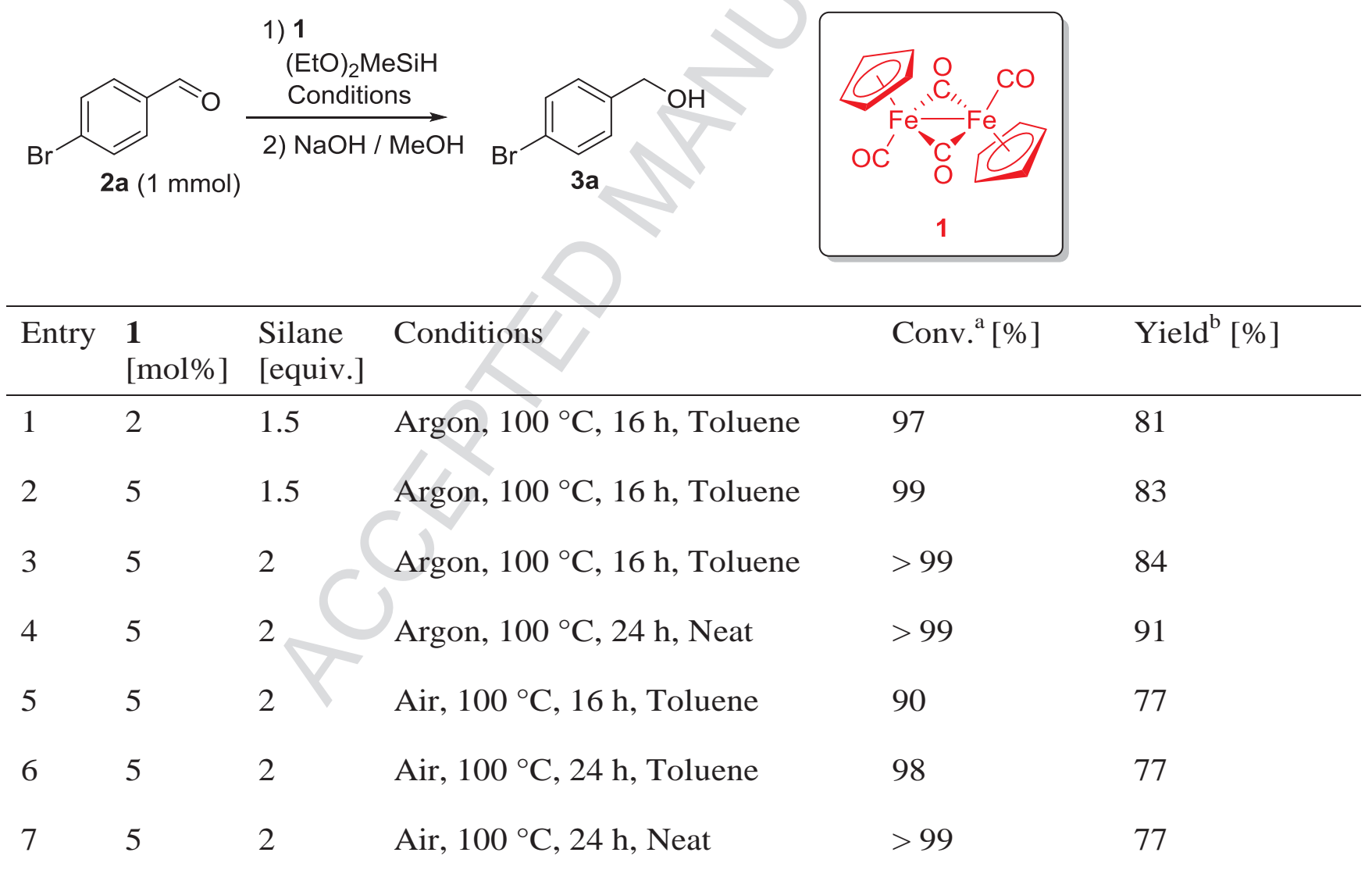

${ }^{a}$ Conversion determined by ${ }^{1} \mathrm{H}$ NMR spectroscopy after basic hydrolysis.

${ }^{\mathrm{b}}$ Isolated yield after purification by column chromatography.

To our delight, increasing the catalyst loading to $5 \mathrm{~mol} \%$ and the amount of hydrosilane to 2 equiv. allowed a full conversion of the aldehyde (entries 2 and 3). We wondered if the excess of silane required for this optimization could advantageously avoid the use of toluene. In fact, the result of the reaction 


\section{ACQEPTED MANUSCRIPTI}

carried out under solvent-free conditions was the same after $24 \mathrm{~h}$ (entry 4). We then probed the stability limits of the iron pre-catalyst $\mathbf{1}$ by running the reduction under air. Gratifyingly, full conversion of 2a was reached within $24 \mathrm{~h}$ under aerobic, solvent-free conditions (entries 5-7). To the best of our knowledge, all iron-based, homogeneous carbonyl hydrosilylation catalyst systems reported to date require exclusion of moisture and oxygen [28]. Our methodology addresses this limitation, greatly increasing the applicability of this reaction. More generally, regardless the central metal, only a handful of complexes allows for efficient hydrosilylation under aerobic conditions [29-35].

A series of representative aldehydes were then catalytically reduced under air using complex $\mathbf{1}$ (Table 2). Overall, near-quantitative conversions were obtained for all (hetero)aromatic and non-aromatic substrates. Of special interest is that no detrimental steric or electronic effects were encountered in the reduction of benzaldehyde derivatives (entries 2-9). High 1,2-selectivity was also observed in the hydrosilylation of cinnamaldehyde (2n) leading to cinnamyl alcohol (3n) with only traces of $\mathbf{3 m}$ present in the crude product (entry 13). After purification, alcohols 3 were isolated in moderate to fairly good yields (44-78\%). This may be attributed to some oxidation of the starting aldehydes in the course of the reaction, owing to its relatively harsh conditions.

\section{Table 2}

Hydrosilylation of aldehydes under air catalysed by 1 .

$$
\begin{aligned}
& \text { 1) }\left[\mathrm{CpFe}(\mathrm{CO})_{2}\right]_{2}(1)(5 \mathrm{~mol} \%) \\
& (\mathrm{EtO})_{2} \mathrm{MeSiH} \text { (2 equiv.) } \\
& \mathrm{R} \curvearrowright \mathrm{O} \quad \stackrel{100{ }^{\circ} \mathrm{C}, 24 \mathrm{~h} \text {, in air }}{\longrightarrow} \quad \widehat{\mathrm{R}} \\
& \text { 2) } \mathrm{NaOH} / \mathrm{MeOH} \\
& \text { 2b-n (1 mmol) 3b-n }
\end{aligned}
$$

\begin{tabular}{llll}
\hline Entry & Aldehyde & Conv. ${ }^{\mathrm{a}}[\%]$ & Yield $^{\mathrm{b}}[\%]$ \\
\hline & 2b: $\mathrm{X}=\mathrm{H}$ & $>99$ & 76 \\
2c: $\mathrm{X}=\mathrm{Me}$ & $>99$ & 71
\end{tabular}


3

4

5

6

7

8

9<smiles>Cc1cccc(C)c1C=O</smiles>

10<smiles>Cc1ccc(C=O)o1</smiles>

$2 k$<smiles>O=Cc1ccc2ccccc2c1</smiles>

21<smiles>O=CCCc1ccccc1</smiles>

$2 m$

2n

$2 j$

12

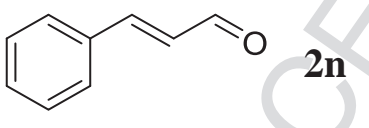

$>99$

$>99$

$>99$

$>99$

$>99$

$>99$

73

$>99$

64

$>99$

78

n.d. ${ }^{\mathrm{c}}$

66

73

76

$>99 \quad$ n.d.

$>99$

76

$>99$

44

72

${ }^{\text {a }}$ Conversion determined by ${ }^{1}$ H NMR spectroscopy after basic hydrolysis.

${ }^{\mathrm{b}}$ Isolated yield after purification by column chromatography.

${ }^{\mathrm{c}}$ Not determined.

In order to assess this, we have in parallel investigated the scope of this reaction with various aldehydes under an inert atmosphere (see Supplementary data). Following the method depicted in entry 3 of Table 1 (Argon, $100{ }^{\circ} \mathrm{C}, 16 \mathrm{~h}$, Toluene), the average isolated yields thus obtained were only $10 \%$ higher than those obtained under aerobic conditions, demonstrating that air confers little detrimental effect. These control experiments also revealed that the presence of oxygen was not necessary to activate pre-catalyst 1. 
We then examined hydrosilylation of a set of ketones using 1 as a pre-catalyst under air (Table 3). For comparison purposes, most of these reactions were also conducted under argon according to conditions described in entry 4 of Table 1 (Argon, $100{ }^{\circ} \mathrm{C}, 24 \mathrm{~h}$, Neat). They showed only slight differences, which are emphasized below where significant (see Supplementary data for details).

Table 3

Hydrosilylation of ketones under air catalysed by 1 .<smiles>[R]C([R])=O</smiles>

1) $\left[\mathrm{CpFe}(\mathrm{CO})_{2}\right]_{2}(1)(5 \mathrm{~mol} \%)$ (EtO) ${ }_{2} \mathrm{MeSiH}$ (2 equiv.) $100^{\circ} \mathrm{C}, 24 \mathrm{~h}$, in air

2) $\mathrm{NaOH} / \mathrm{MeOH}$<smiles>[R]C([R])O</smiles>

4a-o (1 mmol)

5a-o

\begin{tabular}{|c|c|c|c|}
\hline Entry & Ketone & Conv. $^{a}[\%]$ & Yield $^{\mathrm{b}}$ [\%] \\
\hline 1 & 4a: & 96 & 69 \\
\hline 2 & 4b: $X=P h$ & $>99$ & 78 \\
\hline 3 & & $>99$ & 79 \\
\hline 4 & 4d: $X=O M e$ & 85 & n.d. ${ }^{\mathrm{c}}$ \\
\hline 5 & 4e: $\mathrm{X}=\mathrm{CN}$ & $>97$ & n.d. \\
\hline 6 & 4f: $\mathrm{X}=\mathrm{Cl}$ & $>99$ & 93 \\
\hline 7 & $4 g$ & $>98$ & 87 \\
\hline $8^{d}$ & $4 h$ & 92 & 85 \\
\hline $9^{d}$ & $4 \mathbf{i}$ & 83 & 72 \\
\hline
\end{tabular}


$10^{\mathrm{d}}$<smiles>O=C(c1ccccc1)C1CCCCC1</smiles>

$4 \mathbf{j}$<smiles>O=C(Cc1ccccc1)Cc1ccccc1</smiles>

$4 k$

41<smiles>O=C1CC2CCC1C2</smiles><smiles>O=C1c2ccccc2-c2ccccc21</smiles>

14<smiles>O=C(c1ccccc1)c1ccccc1</smiles>

4n

$4 m$

97

96

$68^{\mathrm{e}}$

85

90

n.d.

40<smiles>CC(=O)c1c(F)c(F)c(F)c(F)c1F</smiles>

74

$>99$

78

15

5
(2)

\footnotetext{
${ }^{\mathrm{a}}$ Conversion determined by ${ }^{1} \mathrm{H}$ NMR spectroscopy after basic hydrolysis.

${ }^{\mathrm{b}}$ Isolated yield after purification by column chromatography.

${ }^{\mathrm{c}}$ Not determined.

${ }^{\mathrm{d}}$ Reaction time was $48 \mathrm{~h}$.

e endo/exo $=83 / 17$.
}

Acetophenone (4a) and its para-substituted congeners were efficiently converted to their corresponding secondary alcohols with the exception of 4-methoxyacetophenone (4d) (entries 1-6). With this strongly electron-donating substituent the conversion was only of $85 \%$ in air, but could be satisfyingly raised to 97\% under argon. Propiophenone (4g) also underwent clean reduction (entry 7). For the ketone series, some steric limitations were apparent; conversion was incomplete (74-92\%) for ortho-substituted acetophenones $\mathbf{4 h}, \mathbf{i}$ or cyclohexyl phenyl ketone (4j), even after extended reaction times (entries 8-10). However, these results were far superior to those obtained with the same substrates under argon (48\% 


\section{ACCEPTED MANUSCRIPT}

average conversion). When applying the present method to more challenging carbonyl derivatives, excellent conversions were obtained with dibenzyl ketone (4k), 2-norbornanone (4I), as well as for 9fluorenone (4m) (entries 11-13).

Reduction of benzophenone (4n) under air gave a good result with a conversion of $90 \%$, which even exceeded $96 \%$ under anaerobic conditions. Finally, the activated ketone $\mathbf{4 0}$ was readily converted to its corresponding alcohol (entry 15). Thus, the ability of complex 1 to catalyse the hydrosilylation of less reactive ketones (when compared to aldehydes) under aerobic conditions has been clearly demonstrated.

\section{Conclusions}

In conclusion, cyclopentadienyliron dicarbonyl dimer (1) was identified as a simple tool for the hydrosilylation of aldehydes and ketones in the presence of diethoxymethylsilane. The advantages of the present methodology are: $(i)$ the iron-based pre-catalyst is a ready-to-use complex, $(i i)$ the active species in the catalytic cycle are moisture- and air-stable, (iii) the addition of an organic solvent is unnecessary, (iv) the substrate scope is broad, and (v) the operational simplicity and minimal economic/environmental impact of this catalytic system make it a practical and attractive iron hydrosilylation catalyst.

\section{Acknowledgments}

We thank Université de Rennes 1 and CNRS for financial support.

\section{Footnotes}

" Polymethylhydrosiloxane (PMHS) and triethylsilane were used in the optimization study with 2a (Air, $100{ }^{\circ} \mathrm{C}, 24 \mathrm{~h}$, Toluene) but gave lower conversions.

\section{Appendix A. Supplementary data}


Experimental procedures and analytical data of the products can be found online at http://

\section{References}

[1] M. Zhang, A. Zhang, Appl. Organometal. Chem. 24 (2010) 751.

[2] T. Bleith, H. Wadepohl, L. H. Gade, J. Am. Chem. Soc. 137 (2015) 2456.

[3] Z. Zuo, L. Zhang, X. Leng, Z. Huang, Chem. Commun. 51 (2015) 5073.

[4] N. S. Shaikh, S. Enthaler, K. Junge, M. Beller, Angew. Chem. Int. Ed. 47 (2008) 2497.

[5] T. Inagaki, A. Ito, J.-I. Ito, H. Nishiyama, Angew. Chem. Int. Ed. 49 (2010) 9384.

[6] S. Chakraborty, P. Bhattacharya, H. Dai, H. Guan, Acc. Chem. Res. 48 (2015) 1995.

[7] B. Xue, H. Sun, X. Li, RSC Adv. 5 (2015) 52000.

[8] D. Kumar, A. P. Prakasham, L. Paulin Bheeter, J.-B. Sortais, M. Gangwar, T. Roisnel, A. Ch Kalita, C. Darcel, P. Ghosh, J. Organomet. Chem. 762 (2014) 81.

[9] J. Yang, T. D. Tilley, Angew. Chem. Int. Ed. 49 (2010) 10186.

[10] A. M. Tondreau, E. Lobkovsky, P. J. Chirik, Org. Lett. 10 (2008) 2789.

[11] S. Warratz, L. Postigo, B. Royo, Organometallics 32 (2013) 893.

[12] S. Rommel, C. Belger, J.-M. Begouin, B. Plietker, ChemCatChem 7 (2015) 1292.

[13] D. V. Gutsulyak, L. G. Kuzmina, J. A. K. Howard, S. F. Vyboishchikov, G. I. Nikonov, J. Am. Chem. Soc. 130 (2008) 3732.

[14] S. J. Kraft, R. H. Sanchez, A. S. Hock, ACS Catal. 3 (2013) 826. 
[15] A. J. Ruddy, C. M. Kelly, S. M. Crawford, C. A. Wheaton, O. L. Sydora, B. L. Small, M. Stradiotto, L. Turculet, Organometallics 32 (2013) 5581.

[16] B. Blom, S. Enthaler, S. Inoue, E. Irran, M. Driess, J. Am. Chem. Soc. 135 (2013) 6703.

[17] K. Zhu, M. P. Shaver, S. P. Thomas, Eur. J. Org. Chem. (2015) 2119.

[18] H. Brunner, K. Fisch, J. Organomet. Chem. 412 (1991) C11.

[19] F. S. Wekesa, R. Arias-Ugarte, L. Kong, Z. Sumner, G. P. McGovern, M. Findlater, Organometallics 34 (2015) 5051.

[20] W.-Y Chu, X. Zhou, T. B. Rauchfuss, Organometallics 34 (2015) 1619.

[21] N. S. Shaikh, K. Junge, M. Beller, Org. Lett. 9 (2007) 5429.

[22] E. Buitrago, F. Tinnis, H. Adolfsson, Adv. Synth. Catal. 354 (2012) 217.

[23] T. E. Bitterwolf, Coord. Chem. Rev. 206-207 (2000) 419.

[24] J. R. Vance, A. Schäfer, A. P. M. Robertson, K. Lee, J. Turner, G. R. Whittel, I. Manners, J. Am. Chem. Soc. 136 (2014) 3048.

[25] S. Zhou, D. Addis, S. Das, K. Junge, M. Beller, Chem. Commun. (2009) 4883.

[26] M. Kamigaito, I. Onishi, S. Kimura, Y. Kotani, M. Sawamoto, Chem. Commun. (2002) 2694.

[27] R. S. Srivastava, K. M. Nicholas, Organometallics 24 (2005) 1563.

[28] One heterogeneous catalyst incorporating iron species has also been successfully used under air: M. Li, B. Li, H.-F. Xia, D. Ye, J. Wu, Y. Shi, Green Chem. 16 (2014) 2680.

[29] M. Liang, X. Xia, X. Liu, H. Li, Chin. J. Chem. 33 (2015) 578.

[30] A. J. Huckaba, T. K. Hollis, S. W. Reilly, Organometallics 32 (2013) 6248. 
[31] N. Mostefaï, S. Sirol, J. Courmarcel, O. Riant, Synthesis 8 (2007) 1265.

[32] S. Sirol, J. Courmarcel, N. Mostefaï, O. Riant, Org. Lett. 3 (2001) 4111.

[33] F. Yu, X.-C. Zhang, F.-F. Wu, J.-N. Zhou, W. Fang, J. Wu, A. S. C. Chan, Org. Biomol. Chem. 9 (2011) 5652.

[34] F.-F. Wu, J.-N. Zhou, Q. Fang, Y.-H. Hu, S. Li, X.-C. Zhang, A. S. C. Chan, J. Wu, Chem. Asian J. 7 (2012) 2527.

[35] J.-N. Zhou, Q. Fang, Y.-H. Hu, L.-Y. Yang, F.-F. Wu, L.-J. Xie, J. Wu, S. Li, Org. Biomol. Chem. 12 (2014) 1009 (and references cited therein). 


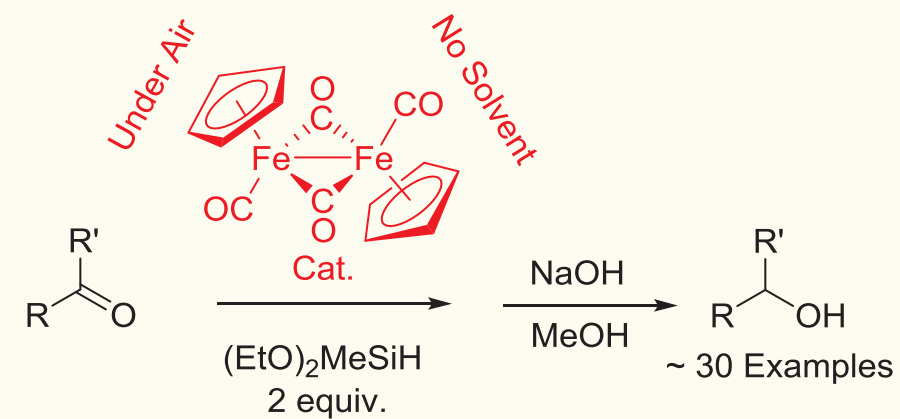

Graphical abstract 
Highlights

- $\quad\left[\mathrm{CpFe}(\mathrm{CO})_{2}\right]_{2}$ promotes hydrosilylation of various aldehydes and ketones

- The procedure is air-tolerant and an organic solvent is unnecessary

- This catalytic system allows a minimal economic and environmental impact 